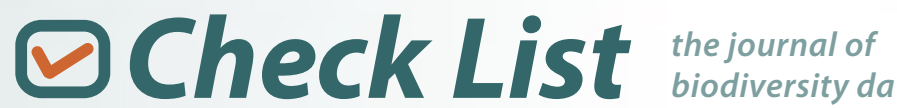

అ

\section{First record of Urotheca dumerilli (Bibron, 1840) (Squamata: Dipsadidae) in Cauca state, Colombia and notes on natural history}

\author{
Luis Enrique Vera-Pérez* and Jorge Alberto Zúñiga-Baos \\ Universidad del Cauca, Grupo de Investigaciones Herpetológicas y Toxinológicas, Departamento de Biología, Vereda Las Guacas, \\ Popayán, Cauca, Colombia \\ * Corresponding author. E-mail: luchoveraperez@gmail.com
}

\begin{abstract}
Urotheca dumerilli has been rediscovered after 44 years through a single specimen collected at sector El Cóndor, Parque Nacional Natural Munchique, municipality of El Tambo, Cauca State, Colombia. Herein we present the coloration in life and description of fully everted hemipenis of the species for first time, with notes on geographical distribution and natural history.
\end{abstract}

Key words: snakes, Munchique, Cauca, Colombia, endemic species, hemipenis

After its description, the genus Urotheca Bibron, 1843 has had several changes according to later opinions and/ or evidences of several authors. First, Dunn (1944) used the name Rhadinaea Cope, 1863 over Urotheca based on the not well-established type species of the latter but thereafter (1957) changed his opinion and suggested that all species of Rhadinaea should be placed in Urotheca and this concept was followed by Roze (1958, 1959, 1964, 1966). Later, Myers (see discussion, 1974) rejected Urotheca and retained Rhadinaea in the interest of nomenclatural stability and proposed several species groups for this genus. Subsequently, Savage and Crother (1989) synonymized the lateristriga group (sensu Myers 1974) and the species of Pliocercus Cope, 1860 within Urotheca based on similarities of hemipenial and tail structures. Although Myers and Cadle (1994) accepted Urotheca, they resurrected Pliocercus, and suggested that both genera are monophyletic sister groups. Finally, Sheehy (2012) synonymized Pliocercus within Urotheca again through molecular evidence.

Urotheca dumerilli, the type species of the genus, was described from a single specimen from "Cuba" but later Myers (1974), suggested that the holotype (Muséum National d'Histoire Naturelle, Paris: MNHM 733) probably came from Colombia, based on three more specimens from this country: one from "Peña Lisa, Condoto, Chocó (British Museum of Natural History, London: BMNH 1914.5.21.46)", another from "Medellín, departamento de Antioquia (American Museum of Natural History, New York: AMNH 35490)" and the last one from "Quebrada Pangala, Río San Juán, Chocó (AMNH 103823)". Forty-four years after the last collected specimen Urotheca dumerilli was found again through a single male individual found active during the day (10:0o h) on 27 July 2013 at sector El Cóndor, Parque Nacional Natural Munchique, municipality of El Tambo, Cauca state $\left(02^{\circ} 43^{\prime} 07.7^{\prime \prime} \mathrm{N}, 076^{\circ} 56^{\prime} 41.5^{\prime \prime} \mathrm{W}, 1,538 \mathrm{~m}\right.$ above sea level) The specimen was deposited in the herpetological collection of the Museo de Historia Natural, Universidad del Cauca, Popayán, Colombia (MHNUC-Se-0oo510).

This new record extends the geographical distribution of the species (Figure 1). In revising the geographical distribution map of the species, we used the following considerations: coordinates from "Peña Lisa, Condoto, Chocó state" were taken from Wilson (1992) and the coordinates from "Quebrada Pangala, Río San Juan, Chocó state" and "Medellín, Antioquia state" were calculated using Google Earth ${ }^{\mathrm{TM}}$ version 7.1.2.2041. We chose an aleatory point within the length of "Quebrada Pangala" located at the municipality of Litoral de San Juan, Chocó state.

Specimen MHNUC-Se-0oo510 has a snout-vent length of $28.4 \mathrm{~cm}$ and an incomplete tail of $9.2 \mathrm{~cm}$. Broken tails have been reported for most species of the lateristriga group including the type species U. dumerilli and even Pliocercus, which also has the disproportionately long and thickened but fragile tails of these snakes (Liner 1960; Wilson 1968; Myers 1974; Savage and Crother 1989). Species identification was based on the taxonomic key and the species diagnosis of Rhadinaea (sensu lato) (Myers 1974) according to the following characteristics: dorsal scale rows 17/17/17; 


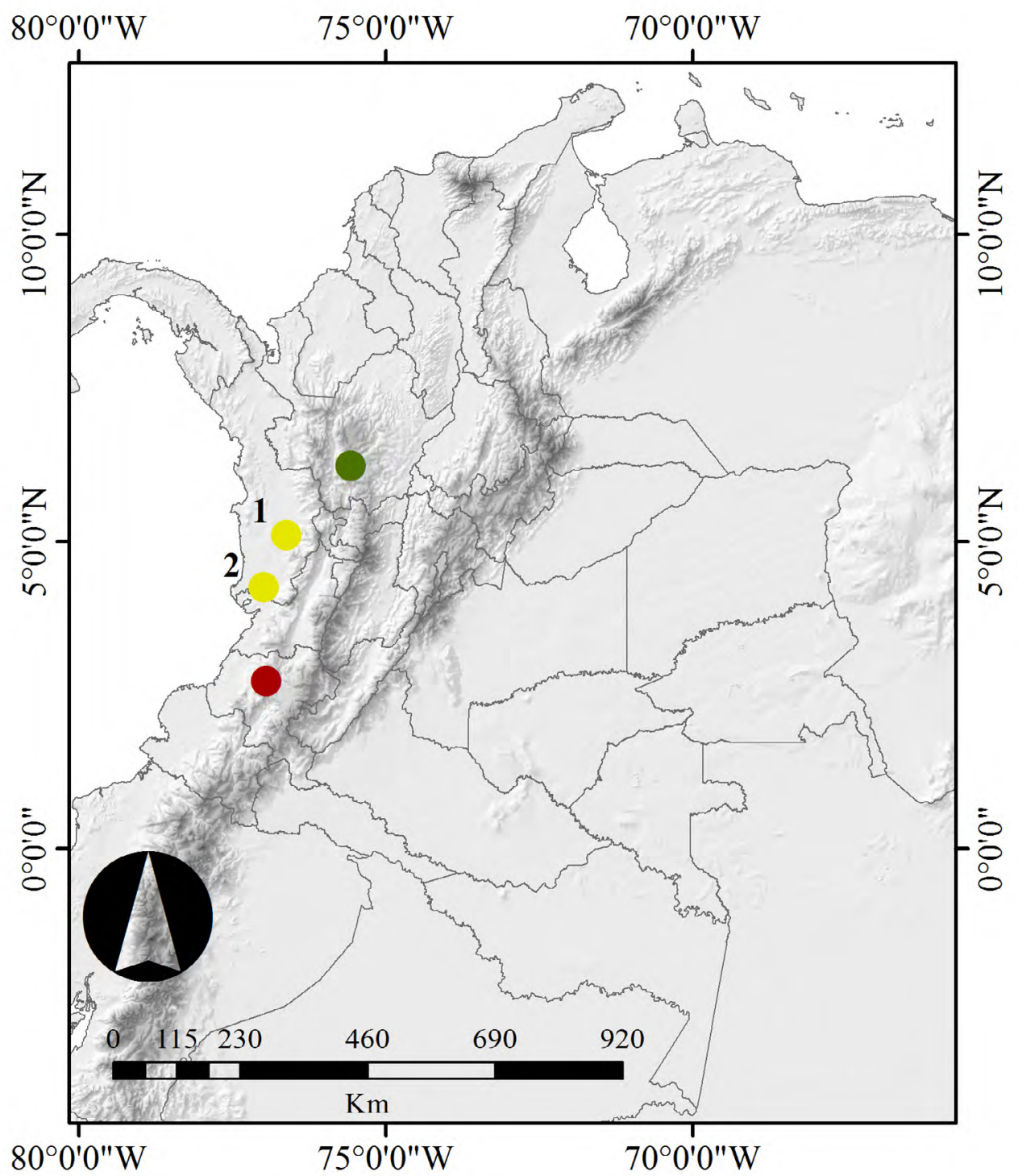

Figure 1. Geographic distribution of the Colombian endemic species Urotheca dumerilli. Green dot indicates Medellín, Antioquia State; Yellow dots indicate (1) Peña Lisa, Condoto and (2) Quebrada Pangala, Río San Juan both from Chocó State; and red dot represents the new locality in Sector El Cóndor, Parque Nacional Natural Munchique, municipality of El Tambo, Cauca State.

postoculars two; preoculars two, subpreocular one; temporals 1+2; supralabials eight, the fourth, fifth and sixth bordering the orbit; infralabials nine, the first six in contact with the chinshields; ventrals 128; subcaudals 41; a single white spot on each side of the neck, above and slightly behind the corner of the mouth.

Dorsal coloration in life of $U$. dumerilli (Figure 2) consists of head and nape light brown, supralabials white, some with dark brown sutures. The brown or grayish brown dorsal color pattern and the "whitish" poorly defined line or narrow stripe that extends from below the angle of the jaws and along the lower one and one-half scale rows of the neck, for a distance of about 12 ventrals described by Myers (1974) are actually dark green and yellow respectively. Ventral coloration in life also differs from Myers' original description and revision of AMNH 103823 one month after its preservation: the venter is not uniform yellowish orange or white but is

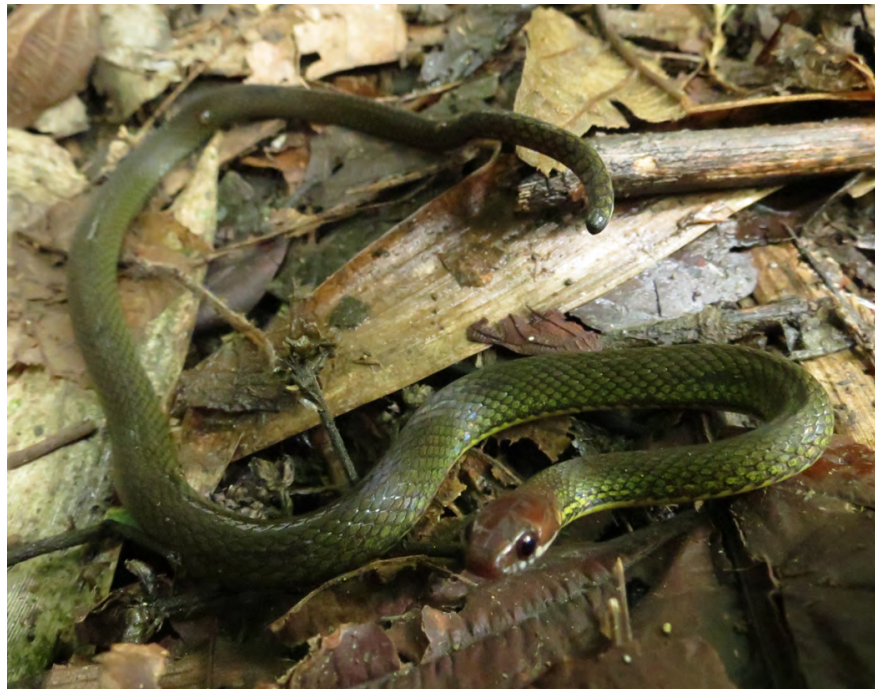

Figure 2. Dorsal coloration in life of Urotheca dumerilli from sector El Cóndor, Parque Nacional Natural Munchique, municipality of El Tambo, Cauca State, Colombia. 


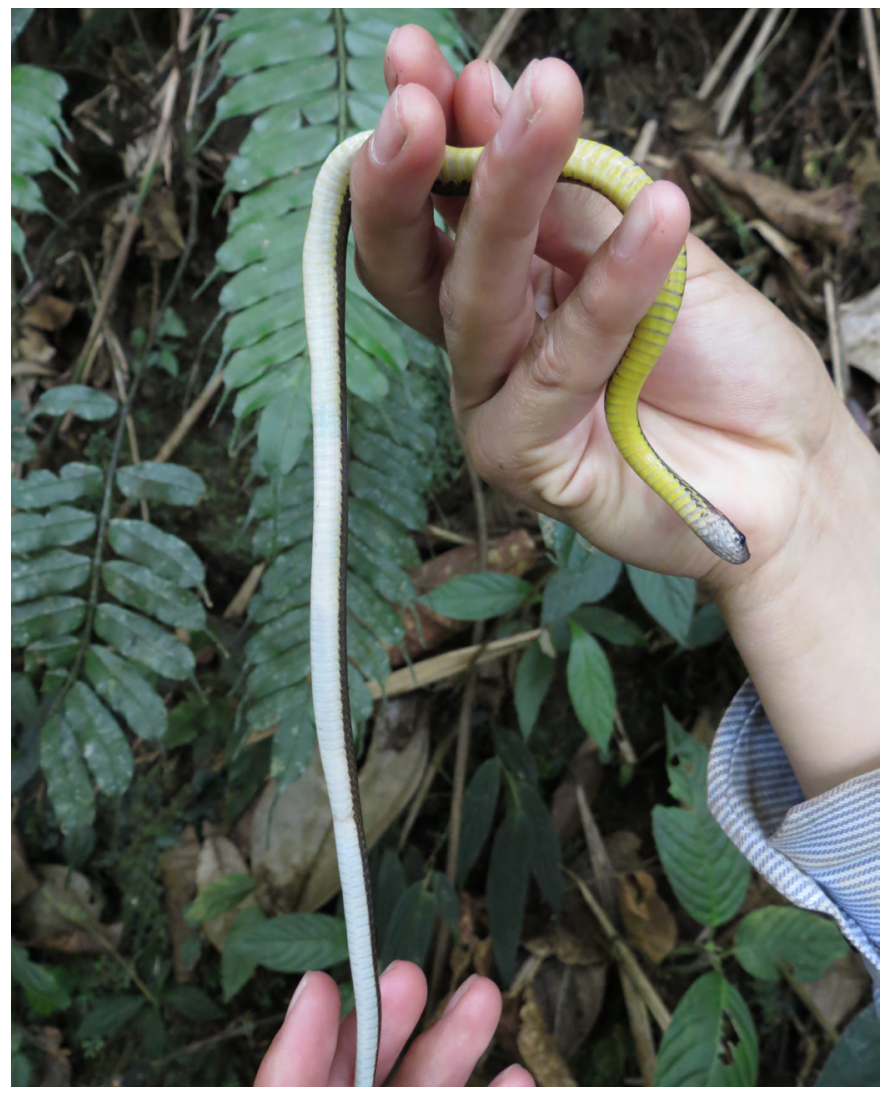

Figure 3. Ventral coloration in life of Urotheca dumerilli from sector El Cóndor, Parque Nacional Natural Munchique, municipality of El Tambo, Cauca State, Colombia. white from the mental to preventral scales, where it becomes yellow and continues to two-thirds of the body length, whereupon it becomes white again until the end of the tail (Figure 3). Coloration changes very quickly in preservative (Figures 2-5). Only four days after fixing in 10\% formalin the dorsal coloration became dark brown, top of head and nape turned reddish and the white and yellow portions of venter (except the tail) became cream and light green respectively (Figure 4). After seven months in $70 \%$ alcohol the dorsal coloration was light brown on the head, nape and anterior portion of the body and dark brown posteriorly while the venter becomes uniformly cream (Figure 5).

The hemipenial description of the holotype of Urotheca dumerilli provided by Myers (1974: 178) is confusing because he says in the text: "The preceding description is based on the left, retracted hemipenis of the holotype, MNHN 733 (illustrated)" but in illustration appears “... right organ", so when the retracted organ is everted it appears as a mirror image and thus the direction of the base of sulcus spermaticus indicates that it is in fact, as the text says, the left organ. The preceding observation also could occur in other illustrations of retracted hemipenis of Rhadinaea (sensu lato) (Myers 1978) in which the direction (left or right) of the base of sulcus spermaticus is evident, with the difference that the organ referred to in text and figures is the same.
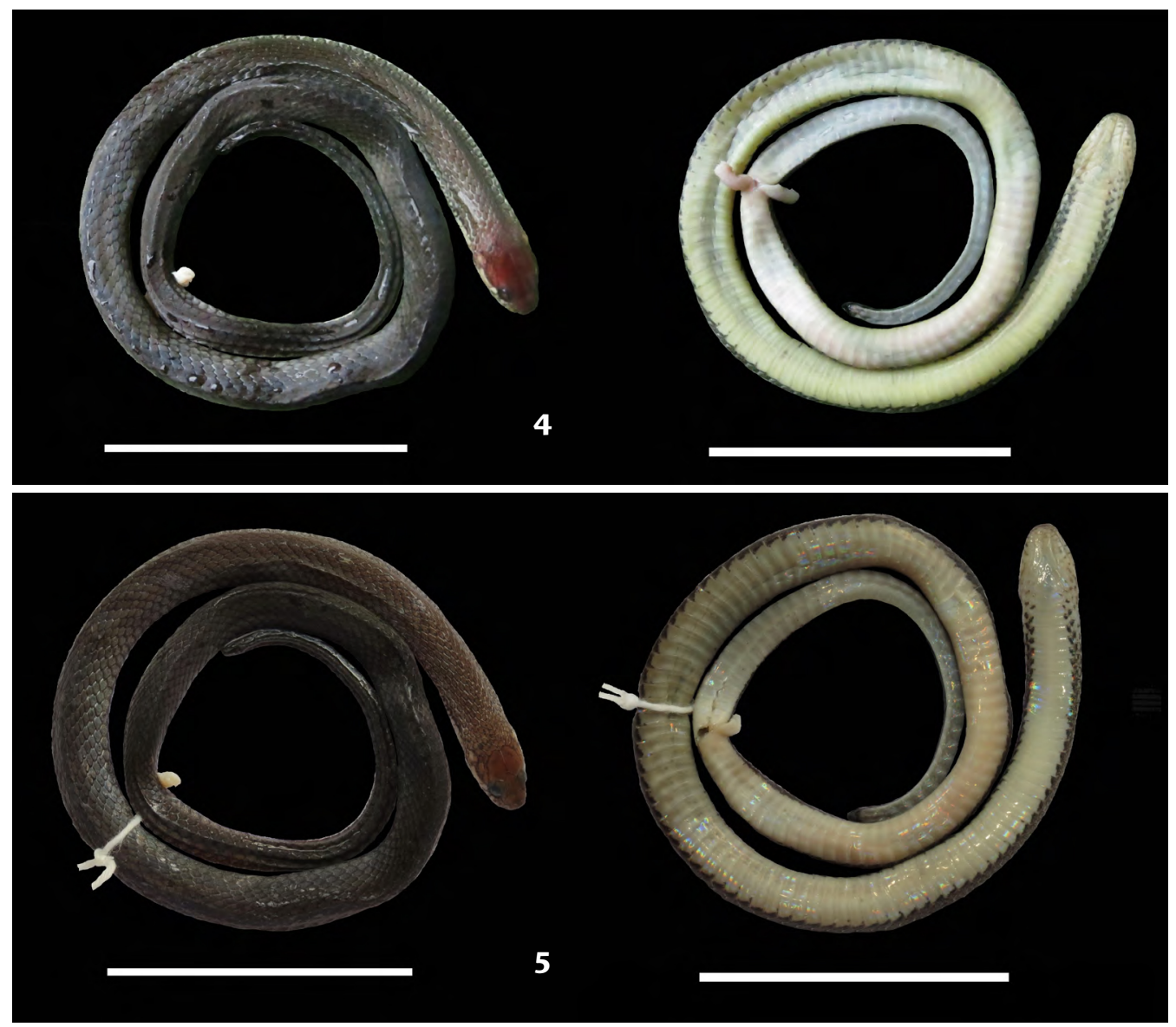

Figures 4-5. Coloration change of Urotheca durmerilli (MHNUC-Se-000510). 4: After four days in 10\% formalin. 5: Seven months in preservative. Scale bars $=50 \mathrm{~mm}$. 


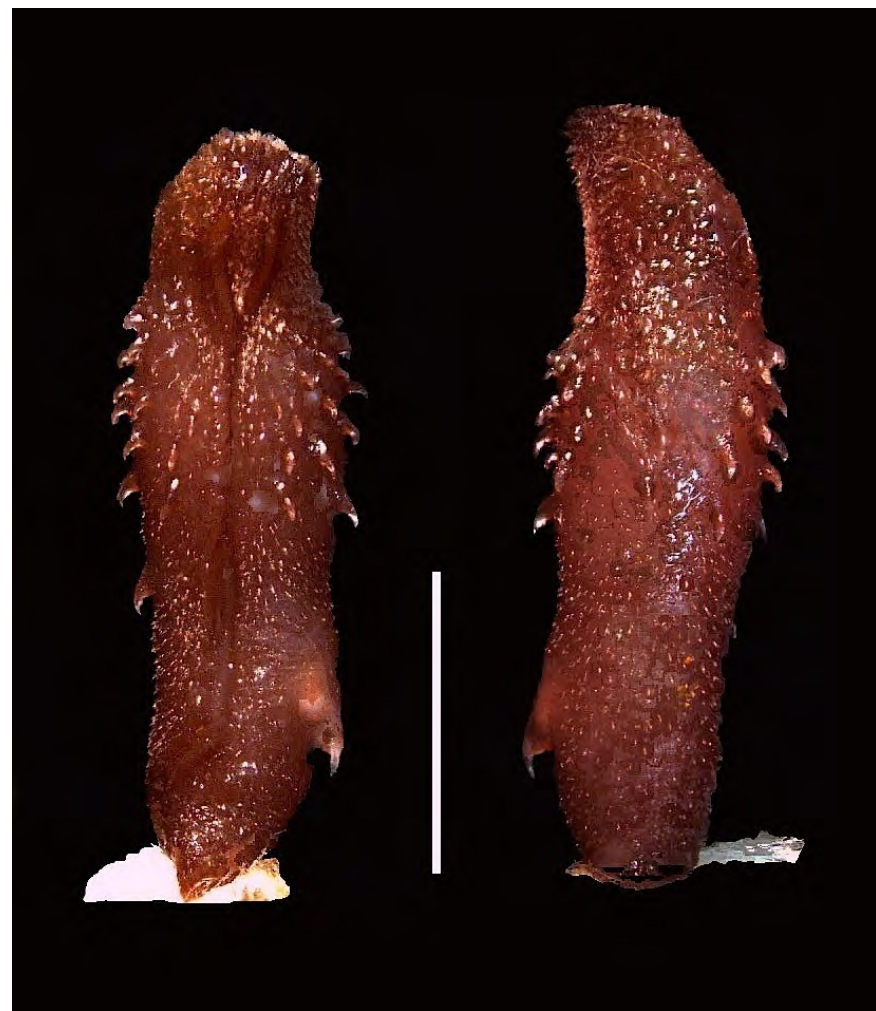

Figure 6. Left hemipenis of Urotheca dumerilli (MHNUC-Se-000510). Sulcate (left) and asulcate (right) surfaces. Scale bar $=5 \mathrm{~mm}$.

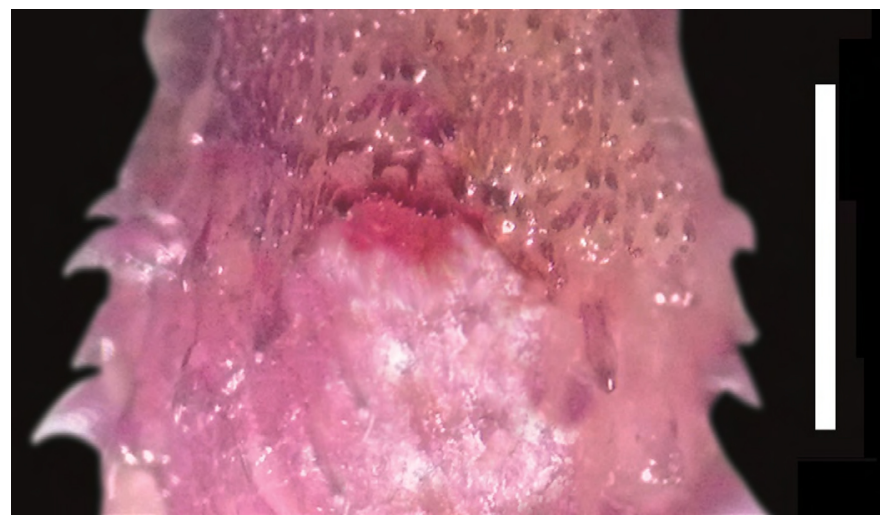

Figure 7. Detail of naked pocket on hemipenial capitulum of Urotheca dumerilli (MHNUC-Se-000510). Asulcate surface of left organ. Scale bar = $2 \mathrm{~mm}$.

Myers (1974) suggested that some observations of the hemipenis of $U$. dumerilli need to be verified, so we herein describe the left hemipenis of specimen MHNUCSe-000510 (Figure 6). We prepared the organ following the methods of Myers and Cadle (2003) and Zaher and Prudente (2003) and almost maximally expanded with the injection of colored petroleum jelly, and stained with Alizarin Red to improve the visualization of calcareous spines (Uzzell 1973).

Unilobed and noncapitate hemipenis of $12.5 \mathrm{~mm}$ total length curved toward the sulcate surface more strongly in the capitulum; proximal portion of hemipenial body is covered by many spinules and a large lateral spine (right side on sulcate view of left organ); distal portion of hemipenial body is covered by 50 mediumsized spines that are longer on the asulcate and lateral surfaces; one of these spines is located proximally to the others (left side of sulcate view); a very small and shallow pocket is present between a nude area at the end of the hemipenial body and the anterior margin of the capitulum on the asulcate surface (Figure 7); lobe covered by small spinules proximally followed by a large number of papillae that form few calyces at the second third of the capitulum length; sulcus spermaticus forked directly in the capitulum with branches that extend almost to the end of the organ. Verification of the presence of a naked pocket on the asulcate surface of the hemipenial capitulum in the type species presented herein reinforces the importance of this character as one of principals to the diagnosis of the genus Urotheca.

At sector El Cóndor, Parque Nacional Natural Munchique, Urotheca dumerilli is sympatric with its easily distinguishable congeners U. lateristriga (Berthold, 1859) and U. euryzonus (Cope, 1862). Although the three species were found only in high anthropically disturbed habitats (e.g., pastures, crops) we cannot suggest that they are strictly associated with this kind of habitat due to its proximity to forest habitats.

Finally, this discovery of Urotheca dumerilli represents the first record in Cauca state, Colombia and extends the distribution of this Colombian endemic species at least $169 \mathrm{~km}$ in a straight line from Quebrada Pangala, municipality of San Juan del Litoral, Chocó state to sector El Cóndor, Parque Nacional Natural Munchique, municipality of El Tambo, Cauca state. Because of the species' geographical distribution along the western slope of the Colombian western cordillera, we believe that it also could be present in Valle del Cauca state.

\section{ACKNOWLEDGEMENTS}

Thanks go to Santiago Ayerbe González, José Beltrán Vidal, Isaac Bedoya Dorado and Jhonattan Vanegas Guerrero for the unconditional support they have given us. Special thanks to Giovanna Gondim Montingelli and Paola María Sánchez from Museu de Zoologia da USP for teaching us the techniques of preparing the hemipenis. Also we thank staff at Unidad de Microscopía Electrónica, Universidad del Cauca for providing us their knowledge and equipment essential to photograph the hemipenes.

\section{LITERATURE CITED}

Dunn, E.R. 1944. A revision of the Colombian snakes of the genera Leimadophis, Lygophis, Rhadinaea, and Pliocercus, with a note on Colombian Coniophanes. Caldasia 2(11): 479-495. doi: $10.2307 / 23640977$

Dunn, E.R. 1957. Neotropical frog genera: Prostherapis versus Hyloxalus with remarks on Phyllobates. Copeia 1957(2): 77-78. doi: $10.2307 / 1439390$

Liner, E.A. 1960. A new subspecies of false coral snake (Pliocercus elapoides) from San Luis Potosí, Mexico. The Southwestern 
Naturalist 5: 217-220. doi: 10.2307/3668945

Myers, C.W. 1974. The systematics of Rhadinaea (Colubridae), a genus of New World snakes. Bulletin of the American Museum of Natural History 153: 1-262. http://hdl.handle.net/2246/605

Myers, C.W. and J.E. Cadle. 1994. A new genus for South American snakes related to Rhadinaea obtusa Cope (Colubridae) and resurrection of Taeniophallus Cope for the "Rhadinaea" brevirostris group. American Museum Novitates 3102: 1-33. http://hdl. handle.net/2246/4934

Myers, C. and J.E. Cadle. 2003. On the snake hemipenis, with notes on Psomophis and techniques of eversion: a response to Dowling. Herpetological Review 34(4): 295-302.

Roze, J.A. 1958. A new species of the genus Urotheca (Serpentes: Colubridae) from Venezuela. Breviora 88: 1-5. http://www. biodiversitylibrary.org/page/3190592

Roze, J.A. 1959. Taxonomic notes on a collection of Venezuelan reptiles in the American Museum of Natural History. American Museum Novitates 1934: 1-14. http://hdl.handle.net/2246/4351

Roze, J.A. 1964. The snakes of the Leimadophis-Urotheca-Liophis complex from Parque Nacional Henri Pittier (Rancho Grande), Venezuela, with a description of a new genus and species (Reptilia, Colubridae). Senckenbergiana Biologica 45: 533-542.

Roze, J.A. 1966. La taxonomia y zoogeografia de los ofidios en Venezuela. Caracas: Universidad Central de Venezuela, Ediciones de la Biblioteca. 362 pp.

Savage, J.M. and B.I. Crother. 1989. The status of Pliocercus and
Urotheca (Serpentes: Colubridae), with a review of included species of coral snake mimics. Zoological Journal of the Linnean Society 95: 335-362. doi: 10.1111/j.1096-3642.1989.tbo2315.x

Sheehy III, C.M. 2012. Phylogenetic relationships and feeding behavior of Neotropical snail-eating snakes (Dipsadinae, Dipsadini) [Ph.D. dissertation]. Arlington, Texas: The University of Texas at Arlington. $126 \mathrm{pp}$.

Uzzell, T.M. 1973. A revision of lizards of the genus Prionodactylus, with a new genus for P. lecostictus and notes on the genus Euspondylus (Sauria: Teiidae). Postilla 159: 1-67.

Wilson, L.D. 1968. A fracture plane in the caudal vertebrae of Pliocercus elapoides (Serpentes: Colubridae). Journal of Herpetology 1: 93-94. doi: 10.2307/1563268

Wilson, L.D. 1992. Tantilla nigra. Catalogue of American Amphibians and Reptiles 548: 1.

Zaher, H. and A.L.C. Prudente. 2003. Hemipenes of Siphlophis (Serpentes, Xenodontinae) and Techniques of Hemipenial Preparation in Snakes: A Response to Dowling. Herpetological Review 34(4): 302-307.

Authors' contribution statement: LEV-P and JAZ-B collected the data and wrote the text. LEV-P edited the figures.

Received: 2 March 2015

Accepted: 16 October 2015

Academic editor: Ross MacCulloch 